\title{
Systematic review of the use of granulocyte-macrophage colony-stimulating factor in patients with advanced melanoma
}

\author{
Christoph Hoeller $^{1} \cdot$ Olivier Michielin $^{2,3} \cdot$ Paolo A. Ascierto $^{4} \cdot$ Zsolt Szabo $^{5} \cdot$ \\ Christian U. Blank ${ }^{6}$
}

Received: 21 December 2015 / Accepted: 15 June 2016 / Published online: 2 July 2016

(c) The Author(s) 2016. This article is published with open access at Springerlink.com

\begin{abstract}
Several immunomodulatory checkpoint inhibitors have been approved for the treatment of patients with advanced melanoma, including ipilimumab, nivolumab and pembrolizumab. Talimogene laherparepvec is the first oncolytic virus to gain regulatory approval in the USA; it is also approved in Europe. Talimogene laherparepvec expresses granulocyte-macrophage colony-stimulating factor (GM-CSF), and with other GM-CSF-expressing oncolytic viruses in development, understanding the clinical relevance of this cytokine in treating advanced melanoma is important. Results of trials of GM-CSF in melanoma have been mixed, and while GM-CSF has the potential to promote anti-tumor responses, some preclinical data suggest that GM-CSF may sometimes promote tumor growth. GMCSF has not been approved as a melanoma treatment. We
\end{abstract}

Electronic supplementary material The online version of this article (doi:10.1007/s00262-016-1860-3) contains supplementary material, which is available to authorized users.

Christoph Hoeller

christoph.hoeller@meduniwien.ac.at

1 Department of Dermatology, Medical University Vienna, Waehringer Guertel 18-20, 1090 Vienna, Austria

2 Department of Oncology, Lausanne University Hospital, Champ de l'Air, Rue du Bugnon 21, 1011 Lausanne, Switzerland

3 Ludwig Centre and Swiss Institute of Bioinformatics, Génopode Building, 1015 Lausanne, Switzerland

4 Istituto Nazionale Tumori, Fondazione 'G. Pascale', Via Mariano Semmola, 52, 80131 Naples, Italy

5 Clinical Development, Amgen Europe GmbH, Dammstrasse 23, $6300 \mathrm{Zug}$, Switzerland

6 Division of Immunology, Netherlands Cancer Institute, Plesmanlaan 121, 1066 CX Amsterdam, Netherlands undertook a systematic literature review of studies of GMCSF in patients with advanced melanoma (stage IIIB-IV). Of the 503 articles identified, 26 studies met the eligibility criteria. Most studies investigated the use of GM-CSF in combination with another treatment, such as peptide vaccines or chemotherapy, or as an adjuvant to surgery. Some clinical benefit was reported in patients who received GMCSF as an adjuvant to surgery, or in combination with other treatments. In general, outcomes for patients receiving peptide vaccines were not improved with the addition of GMCSF. GM-CSF may be a valuable therapeutic adjuvant; however, further studies are needed, particularly headto-head comparisons, to confirm the optimal dosing regimen and clinical effectiveness in patients with advanced melanoma.

Keywords GM-CSF · Granulocyte-macrophage colonystimulating factor $\cdot$ Melanoma $\cdot$ Immunotherapy $\cdot$ Efficacy

$\begin{array}{ll}\text { Abbreviations } & \\ \text { ANC } & \text { Absolute neutrophil count } \\ \text { CI } & \text { Confidence interval } \\ \text { CR } & \text { Complete response } \\ \text { DTH } & \text { Delayed-type hypersensitivity } \\ \text { DTIC } & \text { Dacarbazine } \\ \text { gp100 } & \text { Glycoprotein 100 } \\ \text { MART-1 } & \text { Melanoma antigen recognized by T } \\ & \text { cells 1 } \\ \text { MFG-E8 } & \text { Milk fat globule epidermal growth } \\ & \text { factor } 8 \\ \text { MHP } & \text { Melanoma helper peptide } \\ \text { MP } & \text { Melanoma peptide } \\ \text { MSS } & \text { Melanoma-specific survival } \\ \text { NED } & \text { No evidence of disease } \\ \text { NR } & \text { Not reached }\end{array}$




$\begin{array}{ll}\text { ORR } & \text { Overall response rate } \\ \text { PD } & \text { Progressive disease } \\ \text { PFS } & \text { Progression-free survival } \\ \text { PRISMA } & \begin{array}{l}\text { Preferred reporting items for system- } \\ \text { atic reviews and meta-analyses }\end{array} \\ \text { Q2W/Q3W/Q4W } & \text { Every 2/3/4 weeks } \\ \text { TRP-2 } & \text { Tyrosine-related protein 2 }\end{array}$

\section{Introduction}

Malignant melanoma accounts for approximately $1 \%$ of cancer deaths worldwide, equating to over 55,000 deaths from this tumor type in 2012 [1]. Guidelines for the treatment of cutaneous melanoma recommend surgical resection for localized disease; however, for metastatic disease, systemic therapy is often required [2, 3]. The treatment landscape for advanced or metastatic melanoma has recently changed. Previously, patients received chemotherapy or, in some cases, IL-2 [4, 5]. In Europe, the use of IL-2 is usually recommended only in the context of a clinical trial; however, in patients with metastatic disease who do not have access to a clinical trial program or targeted therapy, IL-2 can be prescribed [3]. In contrast, in the USA, IL-2 is approved for the treatment of patients with metastatic melanoma [6]. The introduction of novel targeted therapies, such as BRAF and MEK inhibitors, and immunomodulatory checkpoint inhibitors, has improved outcomes for patients with advanced disease [7].

Several immunomodulatory agents work by overriding checkpoints in the cancer-immunity cycle, thus promoting the elimination of tumor cells by the immune system [8]. Ipilimumab, a monoclonal antibody that targets the CTLA-4 receptor, and the antibodies nivolumab and pembrolizumab, both of which target PD-1, have been approved in the USA and Europe [9-14]. In October 2015, ipilimumab was approved in the USA for adjuvant therapy in the treatment of patients with cutaneous melanoma with pathologic involvement of regional lymph nodes of more than $1 \mathrm{~mm}$ in diameter who have undergone complete resection, including total lymphadenectomy [9]. Ipilimumab has also been granted accelerated approval in the USA for use in combination with nivolumab for the treatment of patients with unresectable or metastatic wild-type BRAF V600 tumors [11]. Antibodies against PD-L1 (durvalumab [15], avelumab [16] and atezolizumab [17]) are in clinical development.

More recently, oncolytic viruses expressing GM-CSF have been developed, and in 2015, talimogene laherparepvec, a modified herpes simplex virus type 1 , became the first oncolytic virus to gain regulatory approval in the USA, where it is indicated for the local treatment of unresectable cutaneous, subcutaneous (s.c.) and nodal lesions in patients with melanoma recurrent after initial surgery. It has not been shown to improve overall survival (OS) or to have an effect on visceral metastases [18]. Talimogene laherparepvec is also approved in Europe for the treatment of adults with unresectable stage IIIB-IVM1a melanoma that is regionally or distantly metastatic with no bone, brain, lung or other visceral disease [19]. Talimogene laherparepvec has a proposed dual mechanism of action: The introduction of oncolytic viral particles directly into the tumor causes tumor cell lysis and local expression of the gene encoding GM-CSF induces a systemic immune response [20]. There is evidence that the virus causes regression of both the injected and uninjected lesions [21, 22]. In early preclinical studies of talimogene laherparepvec, anti-tumor responses were observed following injection of viruses with and without GM-CSF, but responses in non-injected tumors were observed only in mice that received the GM-CSF-expressing virus [22]. Other modified GM-CSF-expressing oncolytic viruses in early clinical development include JX-594 [23], CG0070 [24] and Ad5/3-D24-GMCSF [25].

In the randomized phase 3 Oncovex ${ }^{\text {GM-CSF }}$ Pivotal Trial in Melanoma (OPTiM), talimogene laherparepvec was compared with s.c. GM-CSF in patients with stage IIIB-IV unresected melanoma [21]. Studies of talimogene laherparepvec in combination with other agents are underway in patients with advanced melanoma, including a phase 2 study of talimogene laherparepvec in combination with ipilimumab [26] and a phase $1 \mathrm{~b} / 3$ trial of talimogene laherparepvec in combination with pembrolizumab [27].

GM-CSF is a hematopoietic growth factor that has pleiotropic effects on the immune system (Fig. 1). It plays an important role in the development and maturation of dendritic cells (DCs) and in the activation and proliferation of $\mathrm{T}$ cells [28]. In response to immune stimuli, GM-CSF is produced by a variety of cell types, such as fibroblasts, epithelial cells, macrophages, T cells and tumor cells [28]. It is an important mediator of the interaction between $\mathrm{T}$ cells and antigen-presenting cells (APCs) and is, therefore, essential for anti-tumorigenic responses [28]. Owing to its immunobiology, GM-CSF has been investigated in clinical trials as both a monotherapy and in combination therapies. GM-CSF (sargramostim) is approved in the USA for the prevention and treatment of chemotherapy-induced neutropenia and for hematopoietic stem cell mobilization [29]. Early studies have shown that it acts as an immune adjuvant to drive humoral and cellular anti-tumor responses [28]. GM-CSF also acts as a chemoattractant for immune cells such as neutrophils [30], which can inhibit or promote tumor activity, depending on the tumor microenvironment. Tumor-associated neutrophils can induce angiogenesis [31], support tumor growth and metastases and suppress the anti-tumor immune response by decreasing the activation 
Fig. 1 Pleiotropic role of GMCSF in tumor immunity [28, 32, 33] GM-CSF, granulocytemacrophage colony-stimulating factor

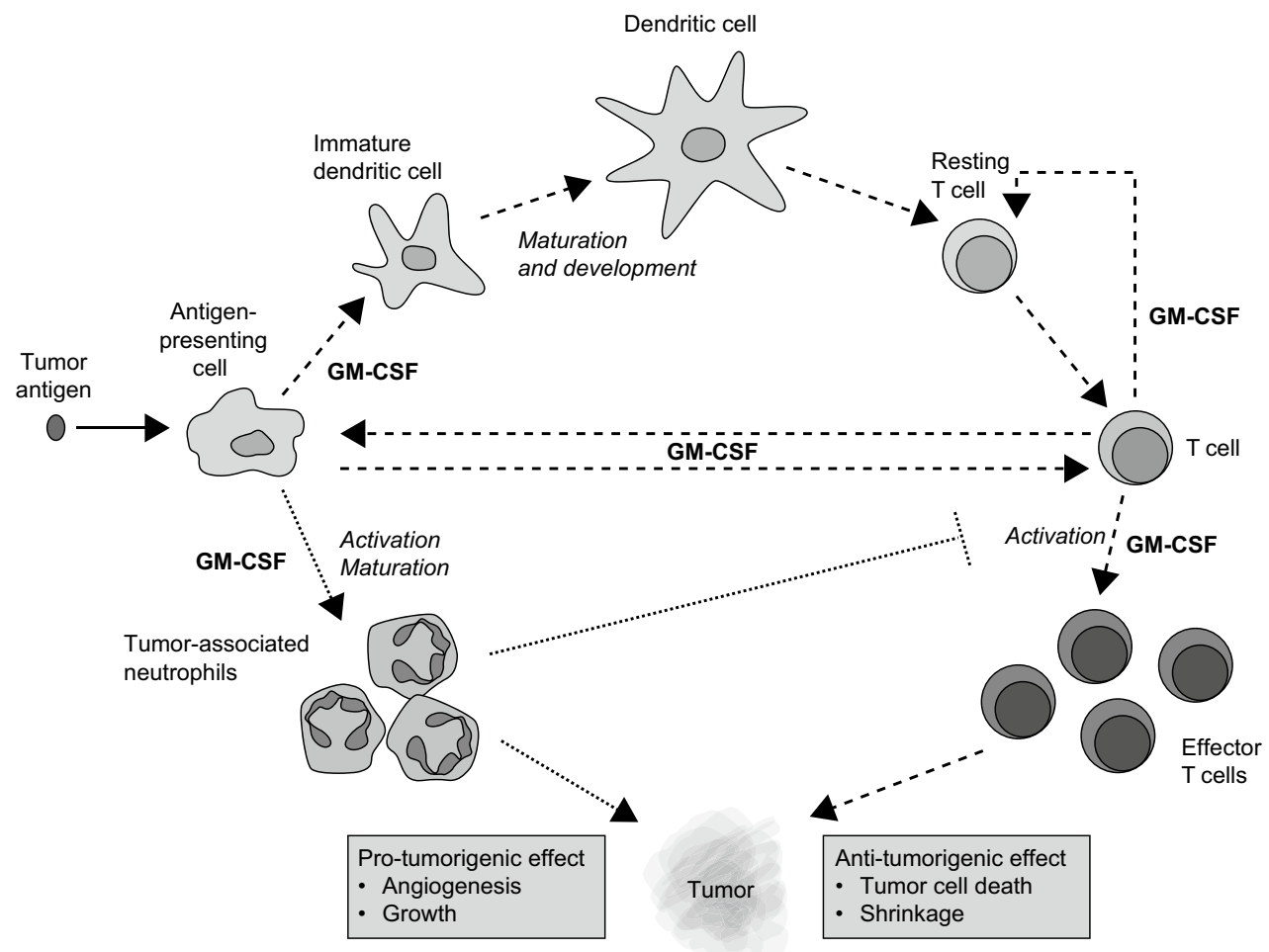

of CD8+ $\mathrm{T}$ cells $[32,33]$. Therefore, in some instances, localized GM-CSF may have a detrimental effect, enabling tumor growth and progression.

One of the mechanisms of cancer immunotherapy is the protection of anti-tumor immune cells from the suppressive effects of certain cell types, such as regulatory $\mathrm{T}$ cells (T-regs) and myeloid-derived suppressor cells (MDSCs). MDSCs are a heterogeneous population of cells that mediate tumor-induced immune suppression. The expansion and recruitment of MDSCs is mediated by several soluble factors, including GM-CSF [34]. Therefore, there have been some concerns that therapeutic GM-CSF may have the potential to induce proliferation of these immunosuppressive cells [35]. MDSC induction has been examined in several murine tumor models. In one model, intratumoral injection of a vaccinia virus expressing GM-CSF had mixed effects on MDSCs: by itself, it increased tumorassociated, but not systemic, MDSCs; co-administration with HER2/neu, however, significantly reduced splenic and tumoral MDSCs [36]. In a model of liver metastases, expansion of MDSCs was dependent on tumor-produced GM-CSF [37]. In contrast to these findings, a different model showed that GM-CSF administered in combination with peptide vaccines caused localized accumulation of DCs and tumor-specific T cells, but no significant increase in the proportion of MDSCs [38]. In another model, tumor infiltration by MDSCs was directly correlated with splenic GM-CSF transcript levels [39]. There is somewhat limited clinical evidence for GM-CSF-mediated induction of MDSCs in patients with melanoma. In a phase 2 study of patients with stage IIIC and IV melanoma, talimogene laherparepvec-treated lesions had lower levels of MDSCs than did specimens derived from patients who had undergone surgical resection [40]. In the same study, analysis of tumor-infiltrating lymphocytes using a MART-1 ELIspot assay showed that talimogene laherparepvec induced a local antigen-specific effector T-cell response and systemic immunity against melanoma antigens. In another study, patients receiving GM-CSF in combination with peptide vaccines and TLR-9 showed that there was no significant change from baseline in the proportion of circulating immunosuppressive cells (T-regs or MDSCs) after treatment [41]. In a prospective trial, no change in MDSCs was observed in patients who received GM-CSF following surgical resection [42].

There is some evidence to suggest that the dose of GMCSF is important in determining immune activation, but other regulatory mechanisms may underlie this process [43]. In normal conditions, GM-CSF induces milk fat globule epidermal growth factor protein 8 (MFG-E8), enabling APCs to phagocytose apoptotic cells, which in turn promotes immune tolerance and may attenuate any anti-tumor responses [44]. In some tumor microenvironments, loss of immune homeostasis and downregulation of MFG-E8 can occur. In this situation, GM-CSF no longer induces tolerance through MFG-E8 and can instead elicit an anti-tumor response [44]. Therefore, MFG-E8 may act as a regulator of GM-CSF function. 
There are few studies reporting data from direct comparisons between GM-CSF and other treatments in patients with advanced melanoma. Therefore, we conducted a systematic review of the available evidence on efficacy, immunological effects and safety of GM-CSF in adult patients with stage IIIB-IV melanoma.

\section{Methods}

\section{Literature search}

We systematically reviewed published English language studies according to a pre-specified protocol. We searched Embase (January 1, 2000-May 1, 2015) and PubMed (January 1, 2000-May 1, 2015). Abstracts from the annual congresses of the following organizations were searched for the period January 1, 2010-April 24, 2015: American Society of Clinical Oncology, European Association of Dermato-Oncology and Society for Melanoma Research. Complete search strings are listed in electronic supplementary material.

\section{Inclusion/exclusion criteria}

Studies were included if they enrolled adults $(\geq 18$ years old) with advanced melanoma (defined as stage IIIB-IV) who received treatment with GM-CSF as monotherapy, as part of combination therapy or in an adjuvant setting. Studies that used modified viruses, cell lines, plasmid DNA or complementary DNA (cDNA) to deliver GM-CSF were excluded. Studies of prevention or detection of melanoma, or those that included patients with non-cutaneous melanoma (e.g., ocular or mucosal melanoma), were also excluded.

\section{Screening and data extraction}

The systematic review process described here is compliant with the 2009 preferred reporting items for systematic reviews and meta-analyses (PRISMA) guidelines [45]. The titles and abstracts of studies identified in the initial search were screened by two independent reviewers to ascertain whether they met the pre-specified inclusion criteria. Phase 1-4 studies, single-arm studies, observational studies, systematic reviews, meta-analyses and pooled analyses were included, but editorials, letters, case reports, guidelines, health technology assessment reports, economic evaluations, narrative reviews and research protocols were excluded from the final analyses.

For all studies that were deemed eligible for inclusion, and for those for which eligibility remained uncertain following the title/abstract screen, the full texts of the study manuscripts were reviewed by two independent reviewers to confirm or refute their eligibility. Data were extracted from full-text publications when available. Data from congress abstracts were included unless the same data had also been published in a peer-reviewed manuscript, in which case only the latter was included in the analysis. A protocol amendment was made at this stage and studies in which fewer than 10 patients received GM-CSF were excluded to focus the analysis on larger studies.

\section{Data analyses}

All data were presented as reported by the authors of the publications analyzed. Mean or median values reported in the studies were used as a basis for summarizing the efficacy, immunological effects and safety of GM-CSF.

\section{Results}

\section{Systematic literature search}

We identified 589 full-text articles and 44 congress abstracts (Fig. 2). Following removal of duplicates, 503 records were analyzed based on title and abstract. At this stage, 371 studies were excluded. The full texts of the remaining articles were screened and a further 106 were excluded, leaving 26 records for analysis. Most were phase 2 studies $(n=16)$, and there were six studies that actively compared GM-CSF with other treatments and three that made comparisons with historical controls.

The study designs and dosing schedules are described in Table 1.

\section{Comparative studies}

Overall, six of the included studies made direct comparisons between GM-CSF treatment and non-GM-CSF treatments [46-51], and three studies compared patients treated with GM-CSF with historical controls who did not receive GM-CSF [52-54].

\section{GM-CSF in combination with systemic therapy}

Significant improvements in OS in patients who received GM-CSF treatment as an adjuvant to systemic therapy were reported in two studies. A phase 2 randomized study reported significantly prolonged median OS when GM-CSF was added to ipilimumab compared with ipilimumab alone (17.5 vs. 12.7 months; $P=0.01$ ) [49]. The 1 -year OS was also significantly improved in the GMCSF group compared with the group receiving ipilimumab alone (1-year OS: 68.9 vs. $52.9 \% ; P=0.01$ ), but median 
Fig. 2 Preferred reporting items for systematic reviews and meta-analyses flow diagram ASCO, American Society of Clinical Oncology; EADO, European Association of Dermato-Oncology

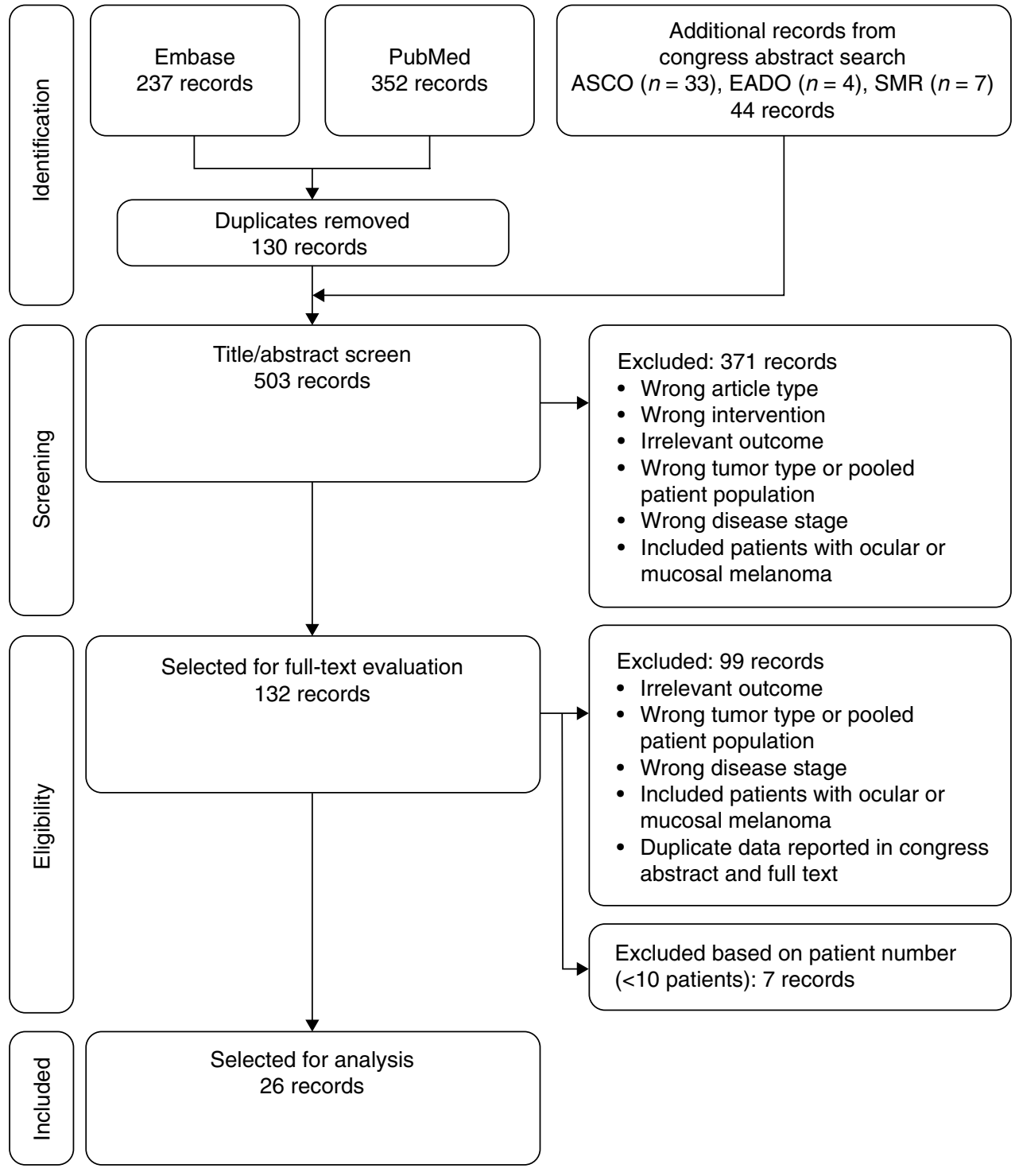

progression-free survival (PFS) was not significantly different between treatment arms (3.1 months each for the GM-CSF group and the ipilimumab group; $P=0.37$ ) [49]. The response rates were similar between groups: 15.5 and $14.8 \%$ in the GM-CSF and ipilimumab-alone groups, respectively [49]. In this trial, significantly fewer grade 3-5 adverse events were reported in patients receiving GM-CSF in combination with ipilimumab than in those receiving ipilimumab alone (44.9 vs. $58.3 \% ; P=0.04$ ); however, there were high numbers of deaths in both treatment groups. The improvements in OS observed in the GM-CSF group may not necessarily be due to increased efficacy when GM-CSF is added to ipilimumab. Reduced toxicity and the resulting lower treatment dropout rate in the GM-CSF arm may have contributed to the observed OS improvement, but this remains to be determined. Furthermore, it is unclear whether treatment discontinuation in the ipilimumab group was due to adverse events or other reasons, such as disease progression [49].

In another phase 2 study, patients who received a novel GM-CSF-containing maintenance biochemotherapy regimen after induction biochemotherapy had significantly longer median OS than historical controls who had received an identical biochemotherapy regimen without GM-CSF (18.5 vs. 9.3 months; $P=0.0004$ ) [53]. The median PFS was also significantly prolonged (GM-CSF, 8.1 months; historical controls, 5.9 months; $P=0.0015$ ), and multivariate analyses showed that maintenance biotherapy was predictive of PFS and OS [53].

Eroglu et al. [52] investigated the use of GM-CSF in combination with docetaxel and vinorelbine. The 1-year OS was $48.1 \%$, which was significantly higher than the predicted survival according to the Korn analysis for this patient group (24.3\%; $P=0.012)$ [52]. 
Table 1 Overview of study designs and GM-CSF dosing schedules

\begin{tabular}{|c|c|c|c|}
\hline Author (year) & Study phase/type & Number of patients enrolled & GM-CSF dosing regimen \\
\hline \multicolumn{4}{|c|}{ Comparator studies (GM-CSF compared with non-GM-CSF treatment) } \\
\hline Schaed et al. [51] & Phase not specified; randomized & 31 & $\begin{array}{l}40 \mu \mathrm{g} \text { i.d. at a single site for } 10 \text { days in combination } \\
\text { with peptide vaccine }\end{array}$ \\
\hline Hersey et al. [48] & Phase $1 / 2$ & 36 & $\begin{array}{l}400 \mu \mathrm{g} \text { s.c.; } \mathrm{Q} 2 \mathrm{~W} \text { in combination with peptide vac- } \\
\text { cine for six vaccinations }\end{array}$ \\
\hline Markovic et al. [50] & Phase 2; randomized & 25 & $\begin{array}{l}10 \text { or } 50 \mu \mathrm{g} \text { s.c. in combination with peptide vaccine; } \\
\mathrm{Q} 3 \mathrm{~W} \text { for eight cycles, then every } 3 \text { months for up } \\
\text { to } 1 \text { year }\end{array}$ \\
\hline Celis et al. [46] & Phase 2; randomized & 28 & $\begin{array}{l}75 \text { or } 100 \mu \mathrm{g} \text { s.c. or no GM-CSF; in combination } \\
\text { with peptide vaccine for up to nine vaccinations or } \\
\text { until PD, excessive toxicity or patient refusal }\end{array}$ \\
\hline Grotz et al. [47] & Retrospective cohort study & 317 & $\begin{array}{l}250 \mu \mathrm{g} \text { s.c. every day for } 14 \text { days of each } 28 \text {-day } \\
\text { cycle as an adjuvant to surgery; treatment contin- } \\
\text { ued for } 1-3 \text { years or until recurrence }\end{array}$ \\
\hline Hodi et al. [49] & Phase 2; randomized & 245 & $\begin{array}{l}250 \mu \mathrm{g} \text { s.c. in combination with ipilimumab on days } \\
1-14 \text { of each } 21 \text {-day cycle }\end{array}$ \\
\hline \multicolumn{4}{|c|}{ Historical comparator studies } \\
\hline Spitler et al. [54] & Phase 2 & 51 & $\begin{array}{l}125 \mu \mathrm{g} / \mathrm{m}^{2} \text { s.c. as an adjuvant to surgery for } 14 \text { con- } \\
\text { secutive days of each } 28 \text {-day cycle; treatment was } \\
\text { continued for } \geq 1 \text { year or until disease recurrence or } \\
\text { significant toxicity }\end{array}$ \\
\hline O'Day et al. [53] & Phase 2 & 33 & $\begin{array}{l}125 \mu \mathrm{g} / \mathrm{m}^{2} \text { s.c. on days } 1-14 \text { (or } 3-17 \text { during pulsed } \\
\text { cycles) for } 12 \text { cycles ( } 28 \text { days per cycle) following } \\
\text { biochemotherapy }\end{array}$ \\
\hline \multicolumn{4}{|c|}{ Comparator studies (GM-CSF used in all arms) } \\
\hline Slingluff Jr et al. [69] & Phase 2 & 39 & $\begin{array}{l}110 \mu \text { g i.d. and s.c. in combination with peptide } \\
\text { vaccine on days } 1,8 \text { and } 15 \text {; these injections were } \\
\text { divided between two injection sites. On days } 29 \text {, } \\
36 \text { and } 43 \text {, one injection was given at the primary } \\
\text { vaccination site only }\end{array}$ \\
\hline Slingluff Jr et al. [70] & Phase 2; randomized & 175 & $\begin{array}{l}110 \mu \mathrm{g} \text { i.d. and s.c. in combination with peptide } \\
\text { vaccine on days } 1,8 \text { and } 15 \text {. On days } 29,36 \text { and } \\
\text { 43, one injection was given at the primary vaccina- } \\
\text { tion site. Treatment was continued as six cycles of } \\
\text { booster vaccinations Q3W for up to } 2 \text { years }\end{array}$ \\
\hline \multicolumn{4}{|l|}{ Single-arm studies } \\
\hline Scheibenbogen et al. [63] & Phase 2 & 18 & $\begin{array}{l}75 \text { or } 150 \mu \mathrm{g} \text { i.d. and s.c. on days } 1-4 \text { and repeated } \\
\text { in weeks } 2,4 \text { and } 6 \text { in combination with peptide } \\
\text { vaccines. If PD was not observed at week } 10 \text {, two } \\
\text { more vaccines were given in week } 10 \text { and week } 14\end{array}$ \\
\hline Groenewegen et al. [58] & Phase $1 / 2$ & 32 & $2.5 \mu \mathrm{g} / \mathrm{kg}$ s.c. on days $2-12$ following chemotherapy \\
\hline Weber et al. [61] & Phase 2 & 31 & $\begin{array}{l}\text { Biochemotherapy: } 125 \mu \mathrm{g} / \mathrm{m}^{2} \text { (maximum dose } \\
250 \mu \mathrm{g} \text { ) s.c. on days } 6-17 \text { of each } 28 \text {-day cycle for } \\
\text { up to eight cycles or beyond at the discretion of the } \\
\text { treating physician }\end{array}$ \\
\hline Fruehauf et al. [57] & Not specified & 10 & $\begin{array}{l}250 \mathrm{mg} / \mathrm{m}^{2} \text { s.c. on days } 2-12 \mathrm{Q} 2 \mathrm{~W} \text { in combination } \\
\text { with chemotherapy }\end{array}$ \\
\hline Boasberg et al. [56] & Not specified & 54 & $\begin{array}{l}\text { Maintenance biotherapy: } 125 \mu \mathrm{g} / \mathrm{m}^{2} \text { s.c. on days } \\
1-14 \text { of each cycle (treatment began } 4 \text { weeks after } \\
\text { the first day of each qualifying patient's last cycle } \\
\text { of concurrent biochemotherapy) }\end{array}$ \\
\hline Pilla et al. [68] & Phase 2 & 38 & $\begin{array}{l}75 \mu \mathrm{g} \text { s.c. on days }-1,0 \text { and }+1 \text { for cycles } 1 \text { and } \\
2, \text { then administered } \mathrm{Q} 2 \mathrm{~W} \text { at the same time as a } \\
\text { peptide vaccine }\end{array}$ \\
\hline Bins et al. [64] & Phase 1 & 11 & $\begin{array}{l}100 \mu \text { g s.c. in combination with tetanus toxoid and } \\
\text { peptide vaccines weekly for } 4 \text { weeks }\end{array}$ \\
\hline
\end{tabular}


Table 1 continued

\begin{tabular}{|c|c|c|c|}
\hline Author (year) & Study phase/type & Number of patients enrolled & GM-CSF dosing regimen \\
\hline Daud et al. [42] & Phase 2 & 42 & $\begin{array}{c}125 \mu \mathrm{g} / \mathrm{m}^{2} \text { s.c. on days } 1-14 \text { of each } 28 \text {-day cycle } \\
\text { (maximum } 13 \text { cycles), as an adjuvant to surgery }\end{array}$ \\
\hline Weide et al. [67] & Phase $1 / 2$ & 15 & $\begin{array}{l}150 \mu \mathrm{g} \text { s.c. } 24 \mathrm{~h} \text { after mRNA injection in weeks } 0,2 \text {, } \\
4 \text { and } 6, \text { then Q4W until week } 34\end{array}$ \\
\hline Dillman et al. [66] & Phase 2 & 56 & $\begin{array}{l}500 \mu \mathrm{g} \text { s.c. weekly for } 3 \text { weeks, then monthly for } \\
5 \text { months (for up to a total of } 6 \text { months or eight } \\
\text { doses) in combination with autologous DCs }\end{array}$ \\
\hline O’Day et al. [62] & Phase 2 & 133 & $\begin{array}{l}\text { Concurrent biotherapy: } 500 \mu \mathrm{g} \text { i.v. on days } 6-16 \text { or } \\
\text { until ANC } \geq 5000 / \mu \mathrm{L} \text { in each } 21 \text {-day cycle. Main- } \\
\text { tenance biotherapy: } 250 \mu \mathrm{g} \text { s.c. on days } 1-14 \text { every } \\
28 \text { days for } 12 \text { cycles }\end{array}$ \\
\hline Spitler et al. [55] & Not specified & 102 & $\begin{array}{l}125 \mu \mathrm{g} / \mathrm{m}^{2} \text { s.c. on days } 1-14 \text { of each } 28 \text {-day cycle; } \\
\text { treatment continued for } \geq 3 \text { years or until unresect- } \\
\text { able recurrence, as an adjuvant to surgery }\end{array}$ \\
\hline Gunturu et al. [59] & Phase 2 & 20 & $\begin{array}{l}250 \mu \mathrm{g} / \mathrm{m}^{2} \text { s.c. daily from day } 8 \text { until ANC recovery, } \\
\text { following chemotherapy }\end{array}$ \\
\hline Locke et al. [60] & Phase 2 & 20 & $\begin{array}{l}250 \mu \mathrm{g} / \mathrm{m}^{2} \text { s.c. on days } 3-12 \text { following chemo- } \\
\text { therapy or until WBC count recovery, whichever } \\
\text { occurred first. Treatment cycles continued Q3W } \\
\text { until progression or toxicity }\end{array}$ \\
\hline Adamina et al. [65] & Phase $1 / 2$ & 16 & $\begin{array}{l}5 \mu \mathrm{g} / \mathrm{kg} \text { s.c. every } 5 \text { days in each } 7 \text {-day cycle, alter- } \\
\text { nating between a week of treatment and a week of } \\
\text { rest over two 7-week courses, in combination with } \\
\text { vaccinia virus }\end{array}$ \\
\hline Eroglu et al. [52] & Phase 2 & 52 & $\begin{array}{l}250 \mathrm{mg} / \mathrm{m}^{2} \text { s.c. on days } 2-12 \mathrm{Q} 2 \mathrm{~W} \text { in combination } \\
\text { with chemotherapy }\end{array}$ \\
\hline
\end{tabular}

$A N C$ absolute neutrophil count, $P D$ progressive disease, $Q 2 W / Q 3 W / Q 4 W$ every $2 / 3 / 4$ weeks

\section{GM-CSF in combination with peptide vaccines}

GM-CSF used in combination with peptide vaccines had no significant effect on survival in two randomized phase 2 studies. In one study, median OS values for patients receiving no GM-CSF, GM-CSF $75 \mu \mathrm{g}$ or GM-CSF $100 \mu \mathrm{g}$ were 10, 6 and 9 months, respectively. This peptide vaccine was deemed clinically ineffective [46]. The other study reported that the addition of low-dose GM-CSF to melanoma peptide (MP) vaccines emulsified in Montanide ISA-51 did not improve median OS or median PFS [50]. In a phase $1 / 2$ study, no clinical responses were reported in patients receiving T-cell peptide epitopes with or without GM-CSF [48].

\section{GM-CSF in the adjuvant setting}

In studies that included patients who received adjuvant GM-CSF following complete surgical resection, most of the participants had stage IIIB or higher disease [47, 54, 55]. In a retrospective cohort study by Grotz et al. [47], adjuvant GM-CSF use was not associated with a significant difference in disease-free or melanoma-specific survival (MSS); however, within a subgroup of patients with stage IIIC disease, a $52 \%$ lower melanoma-specific mortality was reported in individuals receiving GM-CSF than in those who were under observation only (hazard ratio 0.48 ; $P=0.02$ ). The low patient numbers and lack of important information on patient characteristics, such as mutation status or subsequent therapy, make the interpretation of this data set difficult.

Spitler et al. [54] evaluated GM-CSF as an adjuvant therapy in patients who were at high risk of recurrence. Individuals had to have stage III disease with more than four positive nodes and a tumor larger than $3 \mathrm{~cm}$ in diameter. Median OS was significantly prolonged in those who received GM-CSF compared with matched historical controls ( 37.5 vs. 12.2 months; $P=0.001$ ). The 1 -year OS and 2-year OS were also significantly higher in the GM-CSF group than in the control group (89 vs. $45 \%[P=0.001]$ and 64 vs. $15 \%$ [ $P=0.001]$, respectively) [54].

In another study, prolonged GM-CSF treatment was given to patients for at least 3 years following surgical resection. The 5-year MSS rates were 67 and $40 \%$ for patients with stage III and IV disease, respectively [55]. The majority (62/98) of patients had one or more disease recurrences, of which over half were successfully excised [55]. 


\section{Single-arm studies}

Overall, 16 studies in which GM-CSF was not compared with another treatment arm were included. These are summarized in Table 2.

\section{GM-CSF in combination with chemotherapy}

Several single-arm studies evaluated the use of GM-CSF in combination with chemotherapy [52, 56-62]. When docetaxel, vinorelbine and GM-CSF were administered in a study conducted by Fruehauf et al., the overall response rate (ORR) was $50 \%$ and the median time to progression was 8 months [57]. In a similarly designed study, Eroglu et al. [52] reported an ORR of $15.4 \%$. Median OS and PFS were 320 and 134 days, respectively, and the clinical benefit rate was $52 \%$ [52]. In another study, cyclophosphamide and fludarabine were followed by high-dose IL-2 and GMCSF to facilitate granulocyte recovery [59]. The ORR was $22.2 \%$ and estimated median OS and PFS were 1.1 and 0.25 years, respectively [59]. Weber et al. [61] administered daily oral temozolomide followed by biotherapy (GM-CSF in combination with IFN and IL-2) and reported an ORR of $26 \%$. The median PFS was 4.9 months and the overall benefit rate was $48 \%$ [61]. In a phase $1 / 2$ study, dacarbazine (DTIC) followed by GM-CSF, IL-2 and IFN- $\alpha$ resulted in an ORR of $32 \%$ [58].

Two studies assessed biochemotherapy followed by maintenance biochemotherapy [56, 62]. Boasberg et al. stratified survival according to whether or not patients developed vitiligo: Median OS was 18.2 months in patients who developed vitiligo during treatment compared with 8.5 months in those who did not $(P=0.027)$ [56]. O'Day et al. [62] used a similar treatment regimen, but with a higher dose of GM-CSF, and reported a median OS of 13.5 months.

\section{GM-CSF in combination with peptide vaccines}

Scheibenbogen et al. [63] administered GM-CSF at the same site as a peptide vaccine and reported limited clinical efficacy. In another study, no objective responses were reported when GM-CSF was given in combination with a peptide vaccine [64]. More promising results were obtained in a phase $1 / 2$ trial of an intranodal injection of recombinant vaccinia virus followed by soluble peptides and GMCSF [65]. Mean OS was 1106 days in responsive patients and 696 days in non-responsive patients [65].

\section{GM-CSF in combination with other treatments}

In a phase 2 trial of GM-CSF in combination with an autologous DC vaccine, 1-year OS and 5-year predicted
OS were 85 and $54 \%$, respectively [66]. Despite this, no objective responses were recorded [66]. Weide et al. [67] reported no objective responses when autologous mRNA derived from individual metastasizing tumors was administered to patients.

\section{GM-CSF in the adjuvant setting}

In a phase 2 trial, patients with stage IV disease who had undergone surgical resection were given a peptide vaccine and adjuvant GM-CSF followed by IFN- $\alpha$. After one treatment cycle, $55 \%$ of patients had stable disease and $5 \%$ were disease-free. The median OS was 583 days [68]. Two studies with similar designs also used GM-CSF as an adjuvant to surgery. In one study, median OS was 65.3 months and median recurrence-free survival was 5.6 months [42]. In the other study, the 5-year MSS was $67 \%$ for patients with stage III disease and $40 \%$ for those with stage IV disease [55].

\section{Evidence of immune activation by GM-CSF}

Most studies reported evidence of immune activation, and these data are summarized in Table 3. When GM-CSF was used in combination with a peptide vaccine, immunization against peptide-specific antigens was observed. In a single-arm study, proliferative immune responses to six melanoma helper peptides (MHPs) were observed in $81 \%$ of patients [69]. In patients with stage IV disease, peptide vaccines with adjuvant GM-CSF generated CD8+ and CD4+ responses ranging from 0 to $41 \%$ and from 5 to $47 \%$, respectively, across treatment groups, and there was a significant association between CD4+ response and survival $(P=0.0045)[70]$. When immune responses were analyzed by treatment group, $\mathrm{CD} 8+$ and $\mathrm{CD} 4+$ responses were observed in $29.3 \%$ and $16.4-21.1 \%$ of patients, respectively, in those receiving peptide vaccines with GMCSF and Montanide ISA-51 adjuvants [70]. Markovic et al. [50] reported twofold or greater increases from baseline in the number of tetramer-positive cytotoxic $\mathrm{T}$ cells for at least one vaccine-specific peptide in $37.5 \%$ (3/8) of patients who did not receive GM-CSF and in $22.2 \%$ (2/9) and $57.1 \%(4 / 7)$ of those who received GM-CSF 10 and $50 \mu \mathrm{g}$, respectively. When GM-CSF was given in combination with a peptide vaccine in another phase 2 study, there were no differences in immunization efficacy across treatment arms. Therefore, addition of GM-CSF was ineffective at enhancing immunogenicity in this study [46].

Adamina et al. [65] used GM-CSF as an adjuvant following intranodal injection of recombinant vaccinia virus and MPs. All patients had an immune response to the tumor-associated antigen epitope encoded by the vaccinia virus. Furthermore, all $\mathrm{T}$ cells were responsive to in vitro 


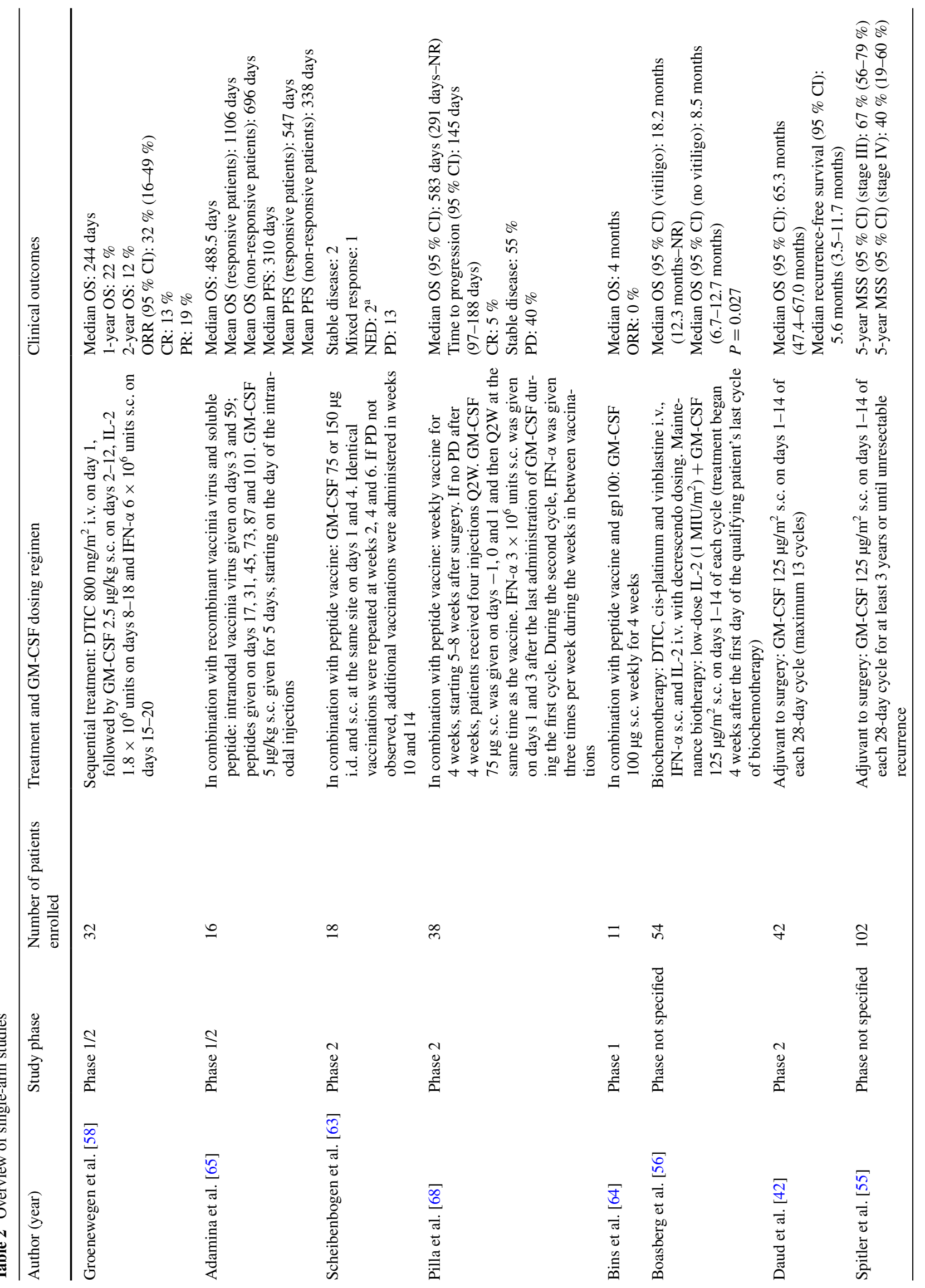




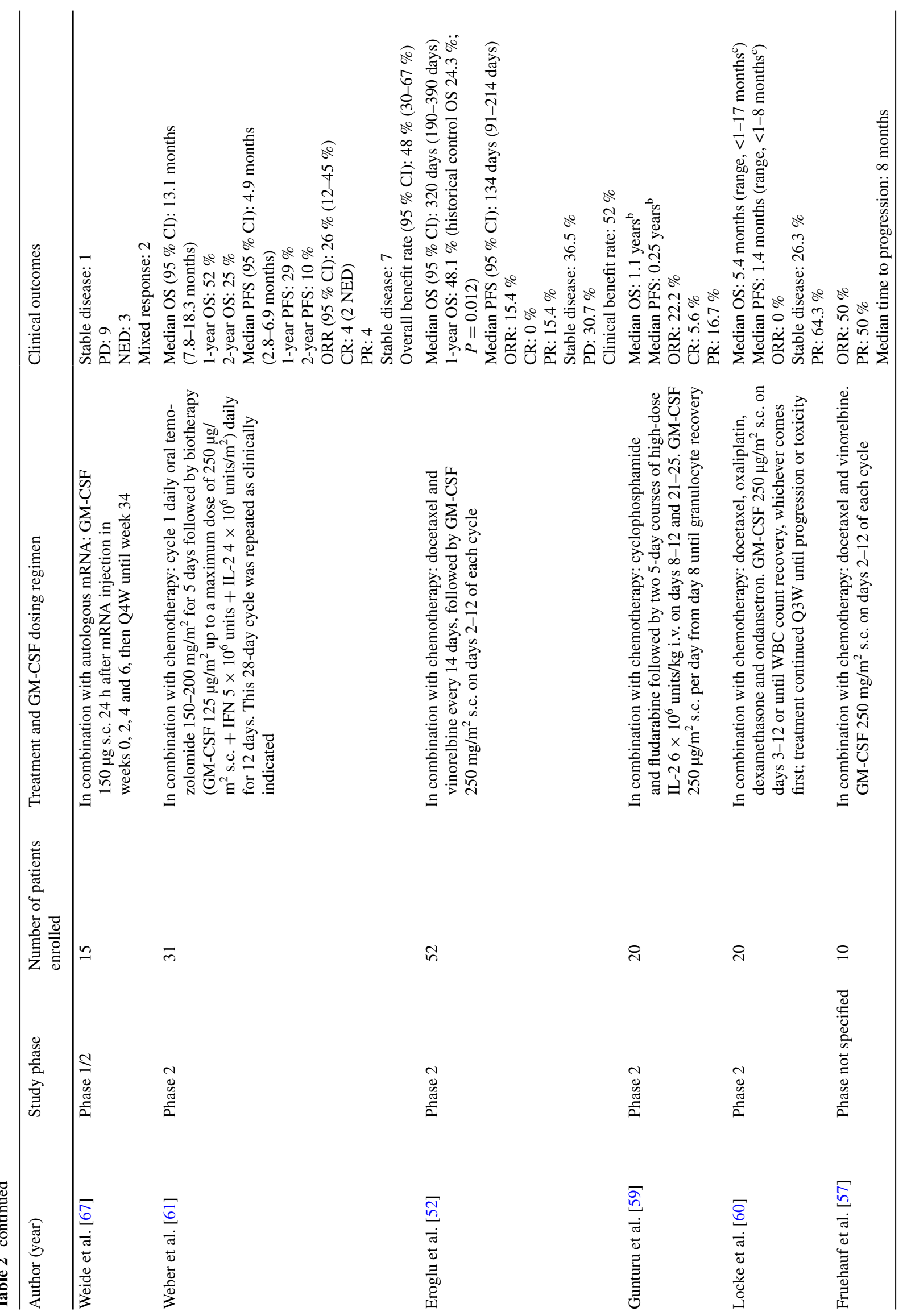




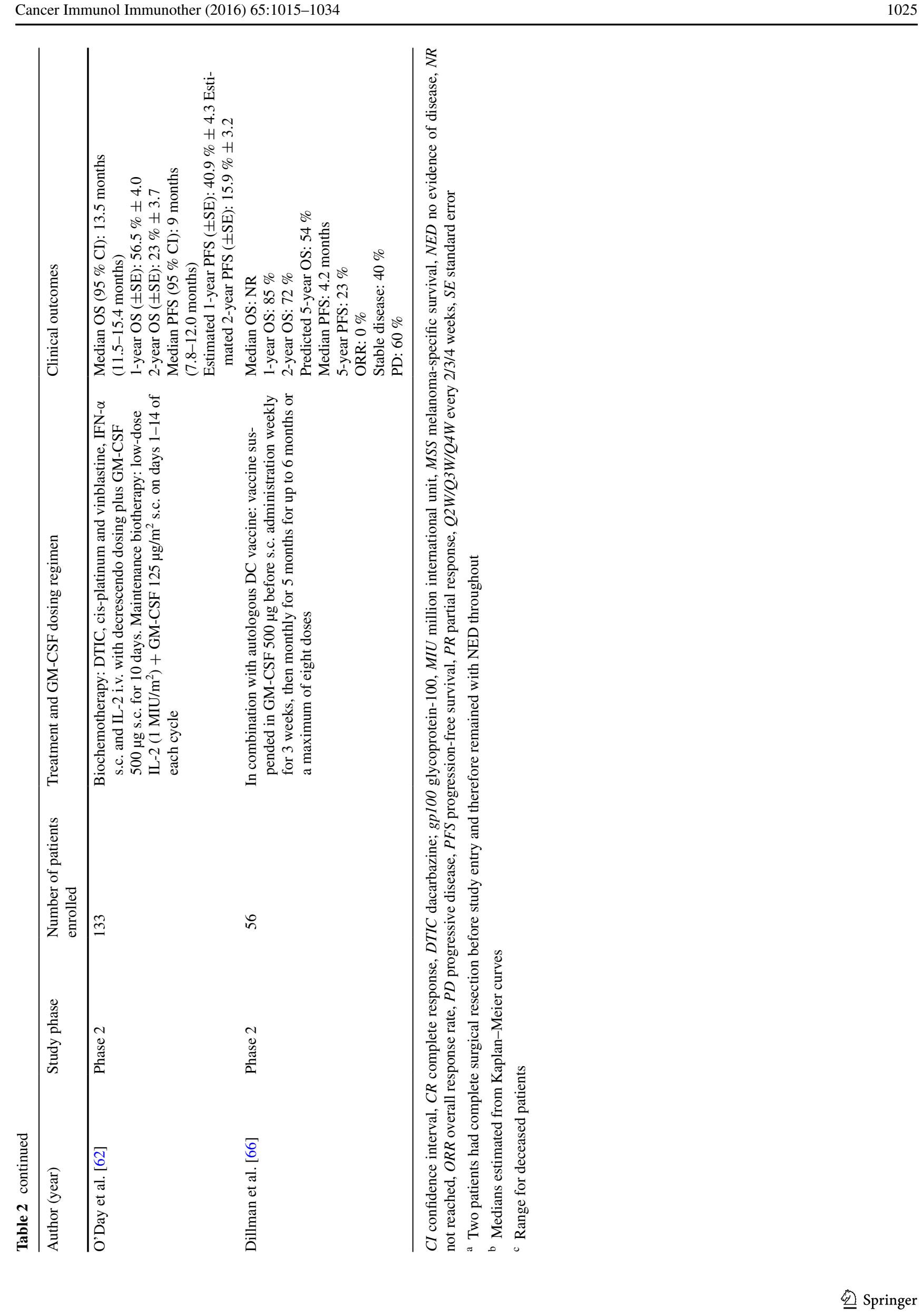




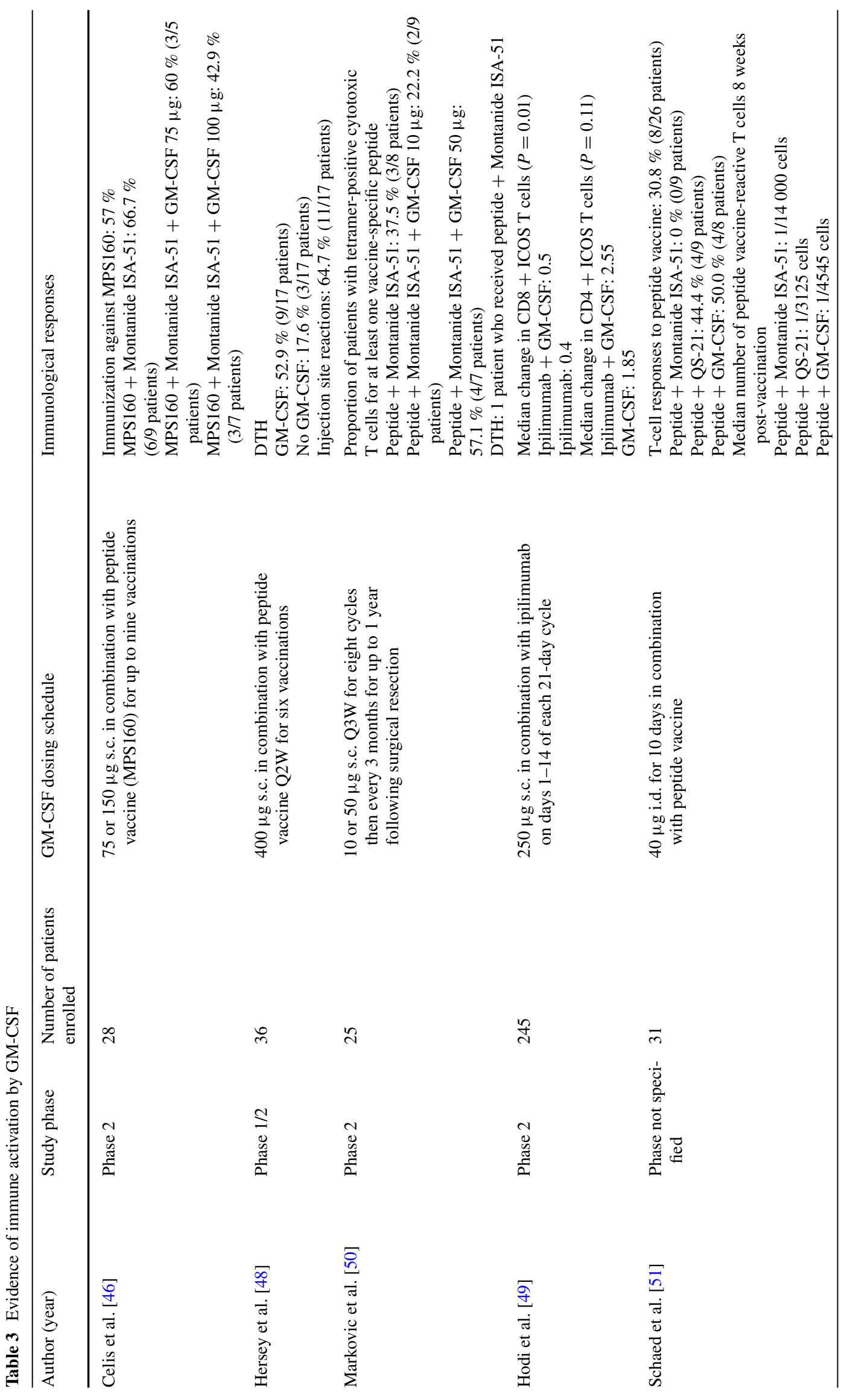




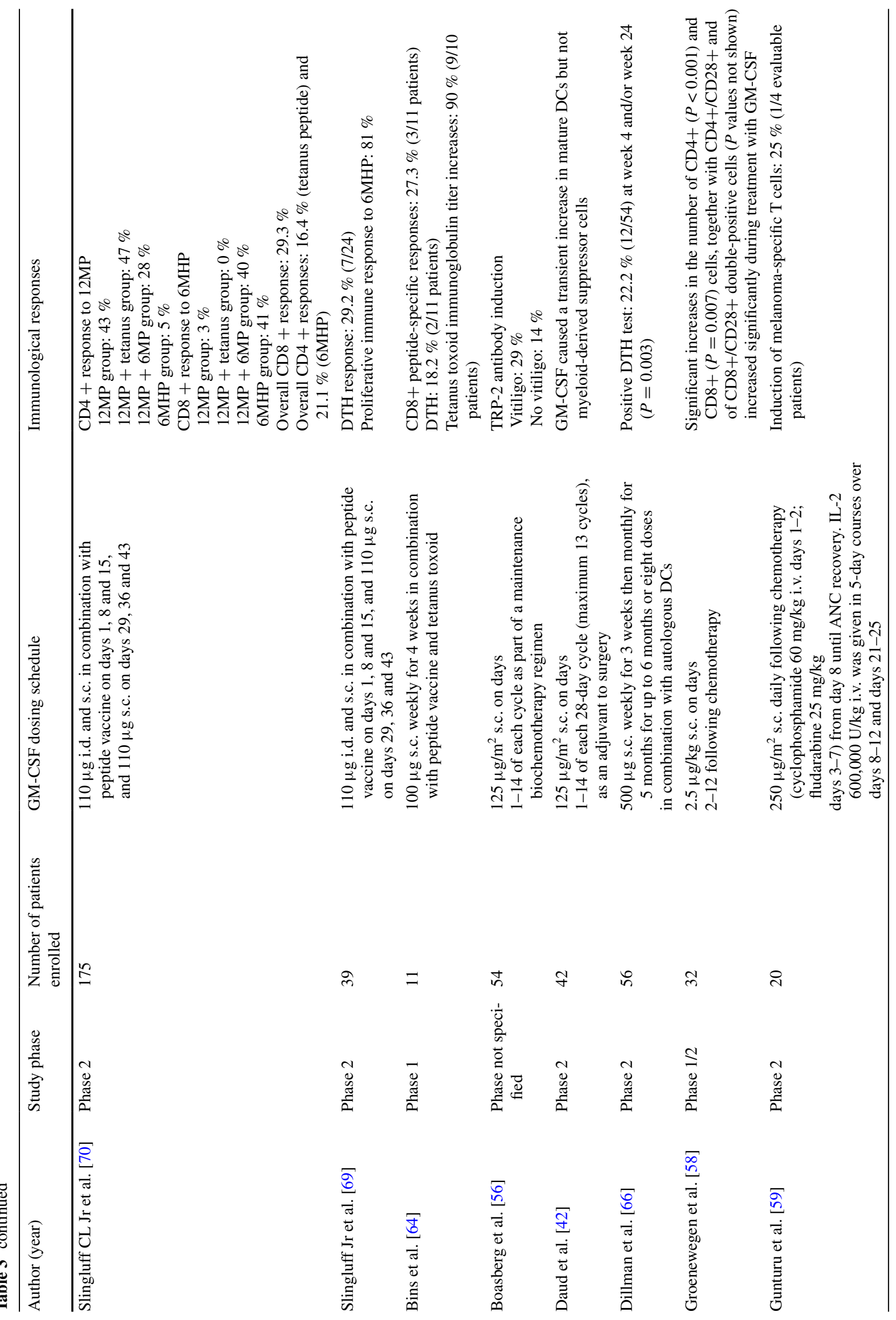




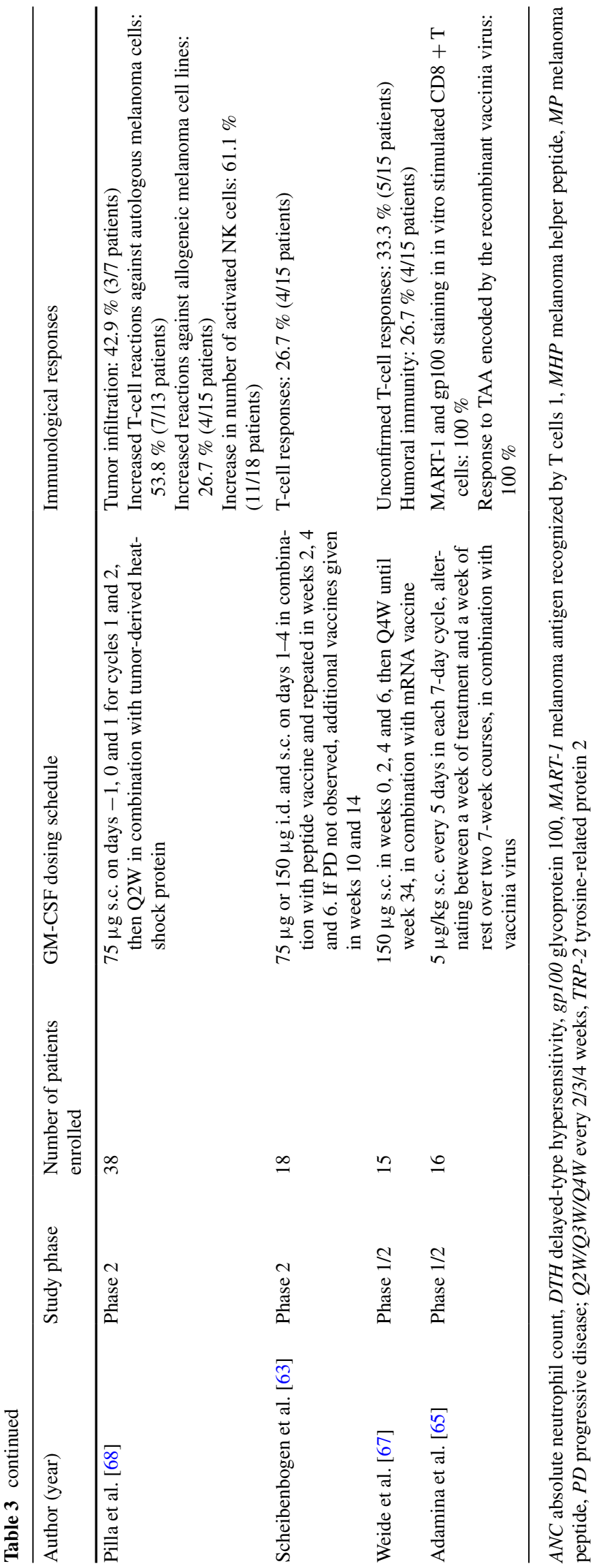


stimulation with the epitopes melanoma antigen recognized by T cells 1 (MART-1) and glycoprotein 100 (gp100) [65]. In another study, positive delayed-type hypersensitivity (DTH) reactions were observed in nine of 17 patients receiving GM-CSF with or without Montanide ISA-720 and in three of 17 patients who did not receive GM-CSF [48]. More severe hypersensitivity reactions were observed in patients receiving GM-CSF and peptides alone than in those receiving GM-CSF and peptides together with Montanide ISA-720. This suggests that GM-CSF may be beneficial only when peptides are not administered together with strong adjuvants [48].

Although signs of peptide-specific immune activation were present in most studies, it appears likely to be nonfunctional due to the lack of correlation with anti-tumor responses [46]. Celis [46] suggest that the phenotypic evidence of immunization in the absence of clinical activity observed in their study was a result of immune dysfunction illustrated by the abnormal cytokine profiles detected in peripheral blood. In another study, Schaed et al. [51] reported no T-cell responses in patients who received the peptide vaccine emulsified in Montanide ISA-51. In those who received the vaccine with the adjuvants QS-21 or GM-CSF, the T-cell response rates were $44.4 \%$ (4/9) and $50.0 \%(4 / 8)$ of patients, respectively. Eight weeks after immunization, the median number of $\mathrm{T}$ cells reactive to the peptide vaccine was highest in the QS-21 adjuvant group (1/3125 cells) followed by the GM-CSF group (1/4545 cells) and the Montanide ISA-51 group (1/14 000 cells). However, this increase was transient, and 2 weeks after completion of treatment, the median number of reactive $\mathrm{T}$ cells was not significantly increased in any of the treatment groups. In this study, clinical benefit was not analyzed, and the magnitude of T-cell response necessary for therapeutic effects has yet to be determined [51]. In another study in which GM-CSF was used as an adjuvant to a peptide vaccine, a cytotoxic T-cell response was observed in only $26.7 \%(4 / 15)$ of patients receiving GM-CSF; these individuals did not have progressive disease (PD) at the time of analysis. Of those who did have PD, no immune reactivity against the peptide vaccine was observed. The majority of patients $(61 \%)$ discontinued the study early owing to disease progression [63].

GM-CSF enhanced the immune response to ipilimumab, as measured by activation of inducible costimulator (ICOS) $\mathrm{T}$ cells. In a phase 2 study evaluating ipilimumab with or without GM-CSF, the median change in CD8+ ICOS $\mathrm{T}$ cells was significantly greater in patients who received ipilimumab and GM-CSF than in those who received ipilimumab alone ( 0.5 vs. $0.4 \% ; P=0.01)$ [49]. Groenewegen et al. [58] reported significant increases from baseline in the number of CD4+ $(P<0.001)$ and CD8+ $(P=0.007)$ cells and a minor increase in the number of natural killer (NK) cells when GM-CSF was used as an adjuvant to chemotherapy. In another study, in which GM-CSF was given as an adjuvant to chemotherapy, induction of melanoma-specific $\mathrm{T}$ cells was observed in one of four evaluable patients. GMCSF was used to support granulocyte recovery in this study, and IL-2 was also given to patients at the same time [59].

When GM-CSF was combined with tumor-derived autologous heat-shock protein gp96, increased T-cell reactions against autologous and allogeneic melanoma cells were observed relative to baseline in $53.8 \%(7 / 13)$ and $26.7 \%(4 / 15)$ of patients, respectively. Increases in the number of NK cells were also observed in $61.1 \%(11 / 18)$ of patients [68]. In another study of adjuvant GM-CSF following surgery, a transient increase in the levels of mature DCs in peripheral blood was observed following GM-CSF treatment, but levels normalized by 4 weeks after the start of treatment [42]. Furthermore, subsequent cycles of GMCSF treatment did not change the levels of mature DCs in peripheral blood [42].

\section{Discussion}

This is the first systematic review of the efficacy of GMCSF in patients with advanced melanoma. Most studies were phase 1 or 2 , but study phase was not reported in some studies; no phase 3 data were available. The study groups varied in size, but most enrolled fewer than 50 patients, and those that had multiple comparator arms often had fewer than 10 patients per treatment group. Furthermore, several studies used historical controls or calculated survival rates as comparators, which makes conclusions from these studies problematic. A range of dosing schedules and routes of administration was used for GM-CSF, but GM-CSF was most often delivered by s.c. injection at a dose of $125-250 \mathrm{mg} / \mathrm{m}^{2}$.

There was some evidence of clinical benefit in patients who received GM-CSF in combination with ipilimumab [49] or as part of a chemotherapy-containing regimen [52, $53,56,57,59,62]$. Ipilimumab is an immunomodulatory checkpoint inhibitor and has an activating effect on the immune system [71]. Therefore, there may be an additive effect when GM-CSF is used with ipilimumab. Stimulation of DCs by GM-CSF upregulates costimulatory molecules that are expressed by DCs, which bind to and activate $\mathrm{T}$ cells; however, the presence of CTLA-4 on T cells inhibits this interaction. Simultaneous inhibition of CTLA-4 and stimulation of DCs would, therefore, be expected to enhance T-cell responses [71]. The clinical benefit observed with the addition of GM-CSF may also be attributed to a reduction in the incidence of adverse events; thus, patients are able to receive more cycles of treatment than those who do not receive it. The potential synergy between immune 
checkpoint inhibitors and GM-CSF is interesting and may warrant further investigation.

The role of chemotherapy in immune activation is less clear, although there is accumulating evidence to suggest that off-target effects of chemotherapy may modulate the innate and adaptive arms of the immune system [72]. Chemotherapy can deplete immune cells because it is indiscriminate in killing rapidly dividing cells, and can also modulate the immune system through several mechanisms. First, it can reduce the number of tumor-induced suppressor cells. Secondly, chemotherapy kills tumor cells, thereby increasing antigenicity and, thirdly, it may directly induce an effector response by activating T cells [72]. DTIC and vinblastine have been shown to induce DC maturation, thereby stimulating immunogenic tumor cell death $[73,74]$. In one phase 2 study, the use of GM-CSF as an adjuvant to chemotherapy was shown to modulate the immune system by inducing $\mathrm{CD} 4+$ regulatory cells, $\mathrm{CD} 8+$ suppressor $\mathrm{T}$ cells and memory $\mathrm{T}$ cells following lymphodepletion [59]. Furthermore, in $25 \%$ of evaluable patients, the circulating melanoma-specific CD8+ cell population was expanded [59]. Hence, a synergistic enhancement of the immune response may occur following administration of GM-CSF to patients receiving chemotherapy; however, many studies of chemotherapy in combination with GM-CSF did not report immunological endpoints. Therefore, it is difficult to draw conclusions on the efficiency of immune activation when these two therapies are used in combination.

Activation of the immune response may correlate with anti-tumor activity. Boasberg et al. assessed a novel biochemotherapy regimen containing GM-CSF and IL-2 and reported that median OS was significantly improved in patients exhibiting immune activation, as indicated by the development of vitiligo [75], compared with those who did not develop the condition [56]. Antibodies against tyrosinase-related protein-2, a protein highly expressed in cutaneous melanoma [76], were detected in a larger proportion of patients with vitiligo than in those without, suggesting increased autoimmunity against melanoma cells in those who developed vitiligo [56]. In another study, patients with immune activation following intranodal injection of a recombinant vaccinia virus were more likely to have a clinical response than those who did not show signs of immune activation [65].

GM-CSF in combination with peptide vaccines showed limited activity. Although T-cell activation was observed in several studies, this was not accompanied by a clinical anti-tumor response [46, 50, 63]. Furthermore, the immune induction observed may be transient, as observed in one study [51]. Although not eligible for inclusion in this systematic review, because it did not report data for our target population separately, a phase 2 randomized study of patients with stage IIB-IV resected melanoma who received a vaccine comprising 12 MPs revealed that addition of GM-CSF did not enhance immunostimulation [77]. Future avenues for the improvement of peptide vaccines include the use of modified adjuvants or long peptides, the inclusion of new antigens and combination therapy with other immunologically active agents [78]. Furthermore, optimization of the GM-CSF dose may be important for inducing immunogenicity. There is evidence that repeated low doses of GM-CSF (40-80 $\mu \mathrm{g}$ for 1-5 days) can enhance vaccine-induced immune responses, but a detrimental effect is observed at higher doses $(100-500 \mu \mathrm{g}$ for 1-5 days) [43]. This may be due to activation of anti-tumor responses at low doses, with higher doses inducing mobilization of MDSCs from the bone marrow and causing subsequent immune suppression [43]. Most studies of peptide vaccines evaluated here used a relatively high dose of GMCSF, which may not be optimal, and they did not investigate MDSC activation. Overall, GM-CSF was well tolerated and did not have a detrimental effect on outcomes.

Generation of anti-GM-CSF antibodies could limit the activity of GM-CSF in vaccines and other treatments. Mice treated with adenoviruses and plasmids engineered to express GM-CSF produced neutralizing antibodies against GM-CSF that were associated with suppressed CD8+ T-cell responses [79]. When GM-CSF was given to patients with metastatic colorectal cancer, $95 \%$ (19 of 20) developed anti-GM-CSF antibodies. In a subset of those patients, development of high-titer anti-GM-CSF responses was accompanied by a significant reduction in GM-CSFinduced granulocytes, although the number of granulocytes did not decrease below baseline values [80]. More recently, a patient with glioblastoma developed grade 3 toxicity following treatment with a DC vaccine in combination with GM-CSF. This sensitization was associated with the production of anti-GM-CSF antibodies and was reversed when GM-CSF treatment was stopped [81]. Although anti-GMCSF antibody production is rarely associated with clinical symptoms, it may reduce the efficacy of GM-CSF in immunotherapy. Therefore, monitoring the development of anti-GM-CSF antibodies during clinical trials of GM-CSF should be considered. Spontaneous development of antiGM-CSF antibodies (in the absence of exogenous GMCSF) has been observed [82], and this should be taken into consideration when analyzing treatment-induced anti-GMCSF antibodies.

The use of GM-CSF as an adjuvant to surgery has shown some clinical benefit, including improvements in OS [54, 55]. Although most patients in these studies were classified as having stage III-IV disease, they were considered to be disease-free at the time of study entry. Therefore, this population may be different from those who are not suitable for surgery, in that they were unlikely to have metastatic disease. Nonetheless, in patients with stage IIIC disease, 
MSS was significantly improved in patients who received GM-CSF following complete surgical resection compared with those who did not receive GM-CSF [47]. Since the completion of this systematic review, a double-blind randomized placebo-controlled phase 3 study has been published in which patients with stage IV or high-risk stage III disease who had undergone surgical resection did not have significantly improved survival following treatment with a peptide vaccine, with or without GM-CSF, compared with placebo [83]. However, exploratory analyses revealed a trend toward improved OS in patients with resected visceral metastases who received GM-CSF compared with those who received placebo [83]. These results suggest that GM-CSF may be effective as an adjuvant treatment to surgery in certain patients; this warrants further investigation.

Overall, GM-CSF in combination with peptide vaccines appears insufficient to induce an immune response that correlates with anti-tumor activity, whereas GM-CSF in combination with chemotherapy [56, 58, 59], autologous melanoma cell vaccine [66], ipilimumab [49] or recombinant vaccinia virus [65] has shown induction of immune responses, together with evidence of some clinical activity, suggesting that use of GM-CSF may be beneficial in combination with agents that stimulate the immune system sufficiently to attack tumor cells.

This systematic review has several limitations. Few studies made direct comparisons between GM-CSF and other treatments, and most involved the use of GM-CSF as an adjuvant to other therapies. Therefore, it was often difficult to distinguish between the effect of the treatment and the effect of GM-CSF on clinical and immunological outcomes. Wide ranges of GM-CSF doses, treatment regimens and comparators were evaluated in the included studies. Establishing the optimal dose of GM-CSF for adjuvant treatment is important to achieve the maximum response [43], and the range of dosing regimens employed by the studies reviewed here suggests that this is yet to be identified. There were also differences in the methodologies used to assess patient outcomes; hence, cross-study comparisons should be made with caution. The treatment groups were often small, making it difficult to extrapolate the results to the wider population of patients with advanced melanoma. Furthermore, GM-CSF is not approved for the treatment of patients with melanoma, so the patient populations described here are likely to be highly selected and may not be representative of those in clinical practice.

In conclusion, it is clear that GM-CSF has been used as an adjuvant in many different clinical trial settings; however, evidence for clinical efficacy is controversial. Some clinical benefit has been observed in patients who received GM-CSF in combination with surgery, chemotherapy or immunomodulatory agents. In general, however, outcomes for patients receiving peptide vaccines were not improved when GM-CSF was used as an adjuvant. GM-CSF is a promising therapeutic adjuvant, but there is a lack of controlled phase 3 trials investigating the direct effects of GMCSF in patients with advanced melanoma. Small, singlecenter studies conducted mostly in academic institutions have not led to the design and implementation of wellcontrolled phase 3 clinical studies. The results presented here indicate that further studies are needed to identify the optimal treatment regimen and effectiveness of GM-CSF in patients with advanced melanoma.

Acknowledgments Open access funding provided by Medical University of Vienna. The systematic review was completed by Liz Hartfield of Oxford PharmaGenesis, Oxford, UK, who also provided medical writing support, funded by Amgen (Europe) $\mathrm{GmbH}$.

Funding This work was funded by Amgen (Europe) GmbH.

\section{Compliance with ethical standards}

Conflicts of interest Christian U. Blank has received research funding from Novartis and is an advisor for Bristol-Myers Squibb, GlaxoSmithKline, Merck Sharp and Dohme, Pfizer, Novartis and Roche. Paolo A. Ascierto has received research funding from Bristol-Myers Squibb, Roche and Ventana. He has also been an advisor for Amgen, Bristol-Myers Squibb, Merck Sharp and Dohme, Novartis, Roche and Ventana. Christoph Hoeller has been an advisor for Amgen, BristolMyers Squibb, GlaxoSmithKline, Merck Sharp and Dohme, Novartis and Roche. Olivier Michielin has no conflicts to declare. Zsolt Szabo is an Amgen employee.

Open Access This article is distributed under the terms of the Creative Commons Attribution 4.0 International License (http://creativecommons.org/licenses/by/4.0/), which permits unrestricted use, distribution, and reproduction in any medium, provided you give appropriate credit to the original author(s) and the source, provide a link to the Creative Commons license, and indicate if changes were made.

\section{References}

1. Ferlay J, Soerjomataram I,Ervik M, Dikshit R, Eser S, Mathers C, Rebelo M, Parkin DM, Forman D, Bray F (2013) GLOBOCAN 2012 v1.0. Cancer Incidence and Mortality Worldwide: IARC CancerBase No. 11. Lyon, France: International Agency for Research on Cancer. http://globocan.iarc.fr. Accessed 26 Jan 2016

2. National Comprehensive Cancer Network (2015) NCCN Clinical Practice Guidelines in Oncology-Melanoma V3.2015. http://www.nccn.org/professionals/physician_gls/pdf/melanoma. pdf. Accessed 22 May 2015

3. Dummer R, Hauschild A, Guggenheim M, Keilholz U, Pentheroudakis G (2012) Cutaneous melanoma: ESMO clinical practice guidelines for diagnosis, treatment and follow-up. Ann Oncol 23(Suppl 7):vii86-vii91. doi:10.1093/annonc/mds229

4. Dummer R, Hauschild A, Guggenheim M, Jost L, Pentheroudakis G (2010) Melanoma: ESMO clinical practice guidelines for diagnosis, treatment and follow-up. Ann Oncol 21(Suppl 5):v194-v197. doi:10.1093/annonc/mdq188

5. NCCN (2009) NCCN Clinical Practice Guidelines in Oncology ${ }^{\mathrm{TM}}$. Melanoma V.2.2009. http://www.mmmp.org/mmmpFile/ 
image/conv\%20ther/NCCN\%20guidelines_Melanoma.pdf. Accessed 5 Oct 2015

6. Prometheus Laboratories Inc. (2015) PROLEUKIN ${ }^{\circledR}$ (aldesleukin) prescribing information. http://www.accessdata.fda.gov/ drugsatfda_docs/label/2012/103293s5130lbl.pdf. Accessed 13 Oct 2015

7. Grimaldi AM, Cassidy PB, Leachmann S, Ascierto PA (2014) Novel approaches in melanoma prevention and therapy. Cancer Treat 159:443-455. doi:10.1007/978-3-642-38007-5_25

8. Chen DS, Mellman I (2013) Oncology meets immunology: the cancer-immunity cycle. Immunity 39:1-10. doi:10.1016/j. immuni.2013.07.012

9. Squibb BM (2015) Yervoy ${ }^{\circledR}$ highlights of prescribing information. http://www.accessdata.fda.gov/drugsatfda_docs/label/2015/ 125377s073lbl.pdf. Accessed 30 Nov 2015

10. Squibb BM (2014) Yervoy ${ }^{\circledR}$ summary of product characteristics. http://www.ema.europa.eu/docs/en_GB/document_library/ EPAR_Product_Information/human/002213/WC500109299.pdf. Accessed 3 Aug 2015

11. Squibb BM (2015) OPDIVO (nivolumab) Highlights of prescribing information. http://www.accessdata.fda.gov/drugsatfda docs/label/2015/125554s002lbl.pdf. Accessed 12 Nov 2015

12. Squibb BM (2015) OPDIVO Summary of product characteristics. http://www.ema.europa.eu/docs/en_GB/document_library/ EPAR_Product_Information/human/003985/WC500189765.pdf. Accessed 3 Aug 2015

13. Sharp M \& Dohme Corp (2014) KEYTRUDA ${ }^{\circledR}$ (pembrolizumab) highlights of prescribing information. http://www. accessdata.fda.gov/drugsatfda_docs/label/2014/125514lbl.pdf. Accessed 3 Aug 2015

14. Sharp M \& Dohme Ltd. (2015) KEYTRUDA summary of product characteristics. http://ec.europa.eu/health/documents/ community-register/2015/20150717132284/anx_132284_en.pdf. Accessed 5 Oct 2015

15. Lutzky J, Antonia SJ, Blake-Haskins A, Li X, Robbins PB, Shalabi AM, Vasselli J, Ibrahim RA, Khleif S, Segal NH (2014) A phase 1 study of MEDI4736, an anti-PD-L1 antibody, in patients with advanced solid tumors. J Clin Oncol 32:(suppl; abstr 3001^)

16. Shitara K, Yamada Y, Yoh K, Naito Y, Iwasa S, Yamamoto N, von Heydebreck A, Achiwa H, Doi T (2015) Phase I, openlabel, multi-ascending dose trial of avelumab (MSB0010718C), an anti-PD-L1 monoclonal antibody, in Japanese patients with advanced solid tumors. J Clin Oncol 33:(suppl; abstr 3023)

17. Spira AI, K Park, Mazières J, Vansteenkiste JF, Rittmeyer A, Ballinger M, Waterkamp D, Kowanetz M, Mokatrin A, Fehrenbacher L (2015) Efficacy, safety and predictive biomarker results from a randomized phase II study comparing MPDL3280A vs docetaxel in 2L/3L NSCLC (POPLAR). J Clin Oncol. 33:(suppl; abstr 8010)

18. Amgen (2015) Imlygic ${ }^{\mathrm{TM}}$ highlights of prescribing information. http://pi.amgen.com/united_states/imlygic/imlygic_pi.pdf. Accessed 12 Nov 2015

19. Amgen (2015) Imlygic summary of product characteristics. Available from: https://www.medicines.org.uk/emc/medicine/31351. Accessed 26 Jan 2016

20. Kaufman HL, Ruby CE, Hughes T, Slingluff CL Jr (2014) Current status of granulocyte-macrophage colony-stimulating factor in the immunotherapy of melanoma. J Immunother Cancer 2:11. doi:10.1186/2051-1426-2-11

21. Andtbacka RH, Kaufman HL, Collichio F et al (2015) Talimogene laherparepvec improves durable response rate in patients with advanced melanoma. J Clin Oncol 33:2780-2788. doi:10.1200/JCO.2014.58.3377

22. Liu BL, Robinson M, Han ZQ et al (2003) ICP34.5 deleted herpes simplex virus with enhanced oncolytic, immune stimulating, and anti-tumour properties. Gene Ther 10:292-303. doi:10.1038/ sj.gt.3301885
23. Hwang TH, Moon A, Burke J et al (2011) A mechanistic proofof-concept clinical trial with JX-594, a targeted multi-mechanistic oncolytic poxvirus, in patients with metastatic melanoma. Mol Ther 19:1913-1922. doi:10.1038/mt.2011.132

24. Burke JM, Lamm DL, Meng MV et al (2012) A first in human phase 1 study of CG0070, a GM-CSF expressing oncolytic adenovirus, for the treatment of nonmuscle invasive bladder cancer. J Urol 188:2391-2397. doi:10.1016/j.juro.2012.07.097

25. Bramante S, Kaufmann JK, Veckman V et al (2015) Treatment of melanoma with a serotype $5 / 3$ chimeric oncolytic adenovirus coding for GM-CSF: results in vitro, in rodents and in humans. International journal of cancer. Int J Cancer 137:1775-1783. doi:10.1002/ijc.29536

26. Puzanov I, Milhem MM, Andtbacka RHI, Minor DR, Hamid O, Li A, Chou J, Kaufman H (2015) Survival, safety, and response patterns in a phase $1 \mathrm{~b}$ multicenter trial of talimogene laherparepvec (T-VEC) and ipilimumab (ipi) in previously untreated, unresected stage IIIB-IV melanoma. J Clin Oncol 33:(suppl; abstr 9063)

27. Ribas A, Puzanov I, Gajewski T et al. (2015) A multicenter, open-label trial of talimogene laherparepvec (T-VEC) plus pembrolizumab vs pembrolizumab monotherapy in previously untreated, unresected, stage IIIB-IV melanoma. J Clin Oncol 33:(suppl; abstr TPS9081)

28. Shi Y, Liu CH, Roberts AI et al (2006) Granulocyte-macrophage colony-stimulating factor (GM-CSF) and T-cell responses: what we do and don't know. Cell Res 16:126-133. doi:10.1038/ sj.cr.7310017

29. Sanofi (2013) Leukine ${ }^{\circledR}$ (sargramostim) prescribing information. http://products.sanofi.us/Leukine/Leukine.html. Accessed 26 Nov 2015

30. Gomez-Cambronero J, Horn J, Paul CC, Baumann MA (2003) Granulocyte-macrophage colony-stimulating factor is a chemoattractant cytokine for human neutrophils: involvement of the ribosomal p70 S6 kinase signaling pathway. J Immunol 171:6846-6855

31. Watnick RS (2012) The role of the tumor microenvironment in regulating angiogenesis. Cold Spring Harb Perspect Med. doi:10.1101/cshperspect.a006676

32. Coffelt SB, Kersten K, Doornebal CW et al (2015) IL-17-producing gamma delta $\mathrm{T}$ cells and neutrophils conspire to promote breast cancer metastasis. Nature 522:345-348. doi:10.1038/ nature 14282

33. Fridlender ZG, Albelda SM (2012) Tumor-associated neutrophils: friend or foe? Carcinogenesis 33:949-955. doi:10.1093/ carcin/bgs 123

34. Dolcetti L, Peranzoni E, Ugel S et al (2010) Hierarchy of immunosuppressive strength among myeloid-derived suppressor cell subsets is determined by GM-CSF. Eur J Immunol 40:22-35. doi:10.1002/eji.200939903

35. Fernandez A, Oliver L, Alvarez R, Fernandez LE, Lee KP, Mesa C (2014) Adjuvants and myeloid-derived suppressor cells: enemies or allies in therapeutic cancer vaccination. Hum Vaccin Immunother 10:3251-3260. doi:10.4161/hv.29847

36. de Vries CR, Monken CE, Lattime EC (2015) The addition of recombinant vaccinia HER2/neu to oncolytic vaccinia-GMCSF given into the tumor microenvironment overcomes MDSC-mediated immune escape and systemic anergy. Cancer Gene Ther 22:154-162. doi:10.1038/cgt.2015.2

37. Burga RA, Thorn M, Point GR et al (2015) Liver myeloidderived suppressor cells expand in response to liver metastases in mice and inhibit the anti-tumor efficacy of anti-CEA CART. Cancer Immunol Immunother 64:817-829. doi:10.1007/ s00262-015-1692-6

38. Dang Y, Wagner WM, Gad E, Rastetter L, Berger CM, Holt GE, Disis ML (2012) Dendritic cell-activating vaccine adjuvants 
differ in the ability to elicit antitumor immunity due to an adjuvant-specific induction of immunosuppressive cells. Clin Cancer Res 18:3122-3131. doi:10.1158/1078-0432.ccr-12-0113

39. Abe F, Dafferner AJ, Donkor M, Westphal SN, Scholar EM, Solheim JC, Singh RK, Hoke TA, Talmadge JE (2010) Myeloid-derived suppressor cells in mammary tumor progression in FVB Neu transgenic mice. Cancer Immunol Immun 59:47-62. doi:10.1007/s00262-009-0719-2

40. Kaufman HL, Kim DW, DeRaffele G, Mitcham J, Coffin RS, Kim-Schulze S (2010) Local and distant immunity induced by intralesional vaccination with an oncolytic herpes virus encoding GM-CSF in patients with stage IIIc and IV melanoma. Ann Surg Oncol 17:718-730. doi:10.1245/s10434-009-0809-6

41. Tarhini AA, Butterfield LH, Shuai Y, Gooding WE, Kalinski P, Kirkwood JM (2012) Differing patterns of circulating regulatory $\mathrm{T}$ cells and myeloid-derived suppressor cells in metastatic melanoma patients receiving anti-CTLA4 antibody and interferonalpha or TLR-9 agonist and GM-CSF with peptide vaccination. J Immunother 35:702-710. doi:10.1097/CJI.0b013e318272569b

42. Daud AI, Mirza N, Lenox B et al (2008) Phenotypic and functional analysis of dendritic cells and clinical outcome in patients with high-risk melanoma treated with adjuvant granulocyte macrophage colony-stimulating factor. J Clin Oncol 26:3235-3241. doi:10.1200/jco.2007.13.9048

43. Parmiani G, Castelli C, Pilla L, Santinami M, Colombo MP, Rivoltini L (2007) Opposite immune functions of GM-CSF administered as vaccine adjuvant in cancer patients. Ann Oncol 8:226232. doi:10.1093/annonc/mdl158

44. Jinushi M, Hodi FS, Dranoff G (2008) Enhancing the clinical activity of granulocyte-macrophage colony-stimulating factorsecreting tumor cell vaccines. Immunol Rev 222:287-298. doi:10.1111/j.1600-065X.2008.00618.x

45. Liberati A, Altman DG, Tetzlaff J et al (2009) The PRISMA statement for reporting systematic reviews and meta-analyses of studies that evaluate health care interventions: explanation and elaboration. Ann Intern Med 151:W65-W94

46. Celis E (2007) Overlapping human leukocyte antigen class I/II binding peptide vaccine for the treatment of patients with stage IV melanoma: evidence of systemic immune dysfunction. Cancer 110:203-214. doi:10.1002/cncr.22744

47. Grotz TE, Kottschade L, Pavey ES, Markovic SN, Jakub JW (2014) Adjuvant GM-CSF improves survival in high-risk stage IIIC melanoma: a single-center study. Am J Clin Oncol 37:467472. doi:10.1097/COC.0b013e31827def82

48. Hersey P, Menzies SW, Coventry B, Nguyen T, Farrelly M, Collins S, Hirst D, Johnson H (2005) Phase I/II study of immunotherapy with T-cell peptide epitopes in patients with stage IV melanoma. Cancer Immunol Immunother 54:208-218. doi:10.1007/s00262-004-0587-8

49. Hodi FS, Lee S, McDermott DF et al (2014) Ipilimumab plus sargramostim versus ipilimumab alone for treatment of metastatic melanoma: a randomized clinical trial. JAMA 312:17441753. doi:10.1001/jama.2014.13943

50. Markovic SN, Suman VJ, Ingle JN et al (2006) Peptide vaccination of patients with metastatic melanoma: improved clinical outcome in patients demonstrating effective immunization. Am J Clin Oncol 29:352-360. doi:10.1097/01.coc.0000217877.78473. a4

51. Schaed SG, Klimek VM, Panageas KS et al (2002) T-cell responses against tyrosinase 368-376(370D) peptide in HLA*A0201+ melanoma patients: randomized trial comparing incomplete Freund's adjuvant, granulocyte macrophage colonystimulating factor, and QS-21 as immunological adjuvants. Clin Cancer Res 8:967-972

52. Eroglu Z, Kong KM, Jakowatz JG, Samlowski W, Fruehauf JP (2011) Phase II clinical trial evaluating docetaxel, vinorelbine and GM-CSF in stage IV melanoma. Cancer Chemother Pharmacol 68:1081-1087. doi:10.1007/s00280-011-1703-z

53. O'Day SJ, Boasberg PD, Piro L et al (2002) Maintenance biotherapy for metastatic melanoma with interleukin-2 and granulocyte macrophage-colony stimulating factor improves survival for patients responding to induction concurrent biochemotherapy. Clin Cancer Res 8:2775-2781

54. Spitler LE, Grossbard ML, Ernstoff MS, Silver G, Jacobs M, Hayes FA, Soong SJ (2000) Adjuvant therapy of stage III and IV malignant melanoma using granulocyte-macrophage colonystimulating factor. J Clin Oncol 18:1614-1621

55. Spitler LE, Weber RW, Allen RE, Meyer J, Cruickshank S, Garbe E, Lin HY, Soong SJ (2009) Recombinant human granulocytemacrophage colony-stimulating factor (GM-CSF, sargramostim) administered for 3 years as adjuvant therapy of stages II(T4), III, and IV melanoma. J Immunother 32:632-637. doi:10.1097/ CJI.0b013e3181a7d60d

56. Boasberg PD, Hoon DS, Piro LD et al (2006) Enhanced survival associated with vitiligo expression during maintenance biotherapy for metastatic melanoma. J Invest Dermatol 126:2658-2663. doi:10.1038/sj.jid.5700545

57. Fruehauf JP, Kong KM, Jakowatz JG (2005) Docetaxel and vinorelbine plus GM-CSF in malignant melanoma. Oncology 19:19-22

58. Groenewegen G, Bloem A, De Gast GC (2002) Phase I/II study of sequential chemoimmunotherapy (SCIT) for metastatic melanoma: outpatient treatment with dacarbazine, granulocyte-macrophage colony-stimulating factor, low-dose interleukin-2, and interferon-alpha. Cancer Immunol Immunother 51:630-636. doi:10.1007/s00262-002-0323-1

59. Gunturu KS, Meehan KR, Mackenzie TA et al (2010) Cytokine working group study of lymphodepleting chemotherapy, interleukin-2, and granulocyte-macrophage colony-stimulating factor in patients with metastatic melanoma: clinical outcomes and peripheral-blood cell recovery. J Clin Oncol 28:1196-1202. doi:10.1200/jco.2009.24.8153

60. Locke F, Clark JI, Gajewski TF (2010) A phase II study of oxaliplatin, docetaxel, and GM-CSF in patients with previously treated advanced melanoma. Cancer Chemother Pharm 65:509514. doi:10.1007/s00280-009-1057-y

61. Weber RW, O’Day S, Rose M et al (2005) Low-dose outpatient chemobiotherapy with temozolomide, granulocyte-macrophage colony stimulating factor, interferon-alpha $2 \mathrm{~b}$, and recombinant interleukin-2 for the treatment of metastatic melanoma. J Clin Oncol 23:8992-9000. doi:10.1200/jco.2005.02.5791

62. O'Day SJ, Atkins MB, Boasberg P et al (2009) Phase II multicenter trial of maintenance biotherapy after induction concurrent biochemotherapy for patients with metastatic melanoma. J Clin Oncol 27:6207-6212. doi:10.1200/jco.2008.20.3075

63. Scheibenbogen C, Schmittel A, Keilholz U, Allgauer T, Hofmann U, Max R, Thiel E, Schadendorf D (2000) Phase 2 trial of vaccination with tyrosinase peptides and granulocyte-macrophage colony-stimulating factor in patients with metastatic melanoma. J Immunother 23:275-281

64. Bins A, Mallo H, Sein J, van den Bogaard C, Nooijen W, VythDreese F, Nuijen B, de Gast GC, Haanen JB (2007) Phase I clinical study with multiple peptide vaccines in combination with tetanus toxoid and GM-CSF in advanced-stage HLA-A*0201positive melanoma patients. J Immunother 30:234-239. doi:10.1097/01.cji.0000211333.06762.47

65. Adamina M, Rosenthal R, Weber WP et al (2010) Intranodal immunization with a vaccinia virus encoding multiple antigenic epitopes and costimulatory molecules in metastatic melanoma. Mol Ther 18:651-659. doi:10.1038/mt.2009.275

66. Dillman RO, Selvan SR, Schiltz PM et al (2009) Phase II trial of dendritic cells loaded with antigens from self-renewing, 
proliferating autologous tumor cells as patient-specific antitumor vaccines in patients with metastatic melanoma: final report. Cancer Biother Radio 24:311-319. doi:10.1089/cbr.2008.0599

67. Weide B, Carralot JP, Reese A, Scheel B, Eigentler TK, Hoerr I, Rammensee HG, Garbe C, Pascolo S (2008) Results of the first phase I/II clinical vaccination trial with direct injection of mRNA. J Immunother 31:180-188. doi:10.1097/ CJI.0b013e31815ce501

68. Pilla L, Patuzzo R, Rivoltini L et al (2006) A phase II trial of vaccination with autologous, tumor-derived heat-shock protein peptide complexes Gp96, in combination with GM-CSF and interferon-alpha in metastatic melanoma patients. Cancer Immunol Immunother 55:958-968. doi:10.1007/s00262-005-0084-8

69. Slingluff CL Jr, Petroni GR, Olson W et al (2008) Helper T-cell responses and clinical activity of a melanoma vaccine with multiple peptides from MAGE and melanocytic differentiation antigens. J Clin Oncol 26:4973-4980. doi:10.1200/jco.2008.17.3161

70. Slingluff CL Jr, Lee S, Zhao F, Chianese-Bullock KA, Olson WC, Butterfield LH, Whiteside TL, Leming PD, Kirkwood JM (2013) A randomized phase II trial of multiepitope vaccination with melanoma peptides for cytotoxic $\mathrm{T}$ cells and helper $\mathrm{T}$ cells for patients with metastatic melanoma (E1602). Clin Cancer Res 19:4228-4238. doi:10.1158/1078-0432.ccr-13-0002

71. Kyi C, Postow MA (2014) Checkpoint blocking antibodies in cancer immunotherapy. FEBS Lett 588:368-376. doi:10.1016/j. febslet.2013.10.015

72. Bracci L, Schiavoni G, Sistigu A, Belardelli F (2014) Immunebased mechanisms of cytotoxic chemotherapy: implications for the design of novel and rationale-based combined treatments against cancer. Cell Death Differ 21:15-25. doi:10.1038/ cdd.2013.67

73. Hervieu A, Rebe C, Vegran F, Chalmin F, Bruchard M, Vabres P, Apetoh L, Ghiringhelli F, Mignot G (2013) Dacarbazine-mediated upregulation of NKG2D ligands on tumor cells activates NK and CD8 T cells and restrains melanoma growth. J Invest Dermatol 133:499-508. doi:10.1038/jid.2012.273

74. Tanaka H, Matsushima H, Nishibu A, Clausen BE, Takashima A (2009) Dual therapeutic efficacy of vinblastine as a unique chemotherapeutic agent capable of inducing dendritic cell maturation. Cancer Res 69:6987-6994. doi:10.1158/0008-5472. can-09-1106

75. Byrne KT, Turk MJ (2011) New perspectives on the role of vitiligo in immune responses to melanoma. Oncotarget 2:684-694

76. Okamoto T, Irie RF, Fujii S, Huang SK, Nizze AJ, Morton DL, Hoon DS (1998) Anti-tyrosinase-related protein-2 immune response in vitiligo patients and melanoma patients receiving active-specific immunotherapy. J Invest Dermatol 111:10341039. doi:10.1046/j.1523-1747.1998.00411.x

77. Slingluff CL Jr, Petroni GR, Olson WC et al (2009) Effect of granulocyte/macrophage colony-stimulating factor on circulating CD8+ and CD4+ T-cell responses to a multipeptide melanoma vaccine: outcome of a multicenter randomized trial. Clin Cancer Res 15:7036-7044. doi:10.1158/1078-0432.ccr-09-1544

78. Slingluff CL Jr (2011) The present and future of peptide vaccines for cancer: single or multiple, long or short, alone or in combination? Cancer J 17:343-350. doi:10.1097/ PPO.0b013e318233e 5b2

79. Tenbusch M, Kuate S, Tippler B, Gerlach N, Schimmer S, Dittmer U, Uberla K (2008) Coexpression of GM-CSF and antigen in DNA prime-adenoviral vector boost immunization enhances polyfunctional $\mathrm{CD} 8+\mathrm{T}$ cell responses, whereas expression of GM-CSF antigen fusion protein induces autoimmunity. BMC Immunol 9:13. doi:10.1186/1471-2172-9-13

80. Ragnhammar P, Friesen HJ, Frodin JE, Lefvert AK, Hassan M, Osterborg A, Mellstedt H (1994) Induction of anti-recombinant human granulocyte-macrophage colony-stimulating factor (Escherichia coli-derived) antibodies and clinical effects in nonimmunocompromised patients. Blood 84:4078-4087

81. Mitchell DA, Sayour EJ, Reap E et al (2015) Severe adverse immunologic reaction in a patient with glioblastoma receiving autologous dendritic cell vaccines combined with GM-CSF and dose-intensified temozolomide. Cancer Immunol Res 3:320-325. doi:10.1158/2326-6066.cir-14-0100

82. Meager A, Wadhwa M, Bird C, Dilger P, Thorpe R, NewsomDavis J, Willcox N (1999) Spontaneously occurring neutralizing antibodies against granulocyte-macrophage colony-stimulating factor in patients with autoimmune disease. Immunology 97:526-532

83. Lawson DH, Lee S, Zhao F et al (2015) Randomized, pPlacebocontrolled, phase III trial of yeast-derived granulocyte-macrophage colony-stimulating factor (GM-CSF) versus peptide vaccination versus GM-CSF plus peptide vaccination versus placebo in patients with no evidence of disease after complete surgical resection of locally advanced and/or stage IV melanoma: a trial of the Eastern Cooperative Oncology Group-American College of Radiology Imaging Network Cancer Research Group (E4697). J Clin Oncol 33:4066-4076. doi:10.1200/jco.2015.62.0500 